\title{
IAMJ
}

INTERNATIONAL

AYURVEDIC

MEDICAL JOURNAL

\section{TO EVALUATE THE EFFICACY OF MADHAVIMOOLA (HIPTAGE BENGHALANSIS ROOT) AS STRI KATIBHAGA KSHEENAKA YOGA - A PILOT STUDY}

\author{
Aabha Sharma \\ MD (Ayu) Assistant Professor, Department of Kayachikitsa, JIAR, Nardani, Jammu (J \& K), India
}

Corresponding Author: aabhashar543@gmail.com

\section{https://doi.org/10.46607/iamj0408102020}

(Published online: October 2020)

Open Access

(C) International Ayurvedic Medical Journal, India 2020

Article Received: 07/09/2020 - Peer Reviewed: 28/09/2020 - Accepted for Publication: 03/10/2020

Check for updates

\section{ABSTRACT}

Background: Obesity (Medo Roga) is a Kapha Pradhana, Atibrimhana Janya Vyadhi, where Shleshma Dosha seated in (Medodhatu). According to Ayurvedic perspective, it is clear that Kledaka Kapha, Samana-Vyana Vata, Pachaka Pitta, Medo Dhatu and Medodhatwagni are involved in the pathogenesis of Medo Roga ${ }^{l}$. The excessively increased Asthayi Medo Dhatu is Ama in nature, due to which it is retained in the body for a longer period resulting in further complications. For this Langhana treatment is mainly highlighted in Grantha ${ }^{2}$. The challenging nature (relapsing) of the disease makes it difficult to be treated. Aim and Objective: The aim of the present study was to evaluate the efficacy of Madhavimoola in the reduction of female waist circumference. Settings and Design: Single arm, Open Randomised clinical trial. Materials and Methods: Here, Madhavimoola is selected for the study to evaluate its efficacy over female's waist circumference, on 30 patients for 45 days on empty stomach with (Nisneha Takra) fat-free buttermilk, early in the morning, in single group. Results: The results were highly significant $(\mathrm{p}<0.001)$ in the objective criteria $\rightarrow$ Waist Circumference, Hip Circumference, Waist-Hip Ratio, Weight, except than in BMI $=0.161$. In subjective criteria Abdomen-Breast movements (Udara-Stana Chalatva) and symptom of weakness (Daurbalya) showed significant difference $(\mathrm{p}=0.016)$. Conclusion: The study showed good results in reducing waist circumference (Katibhaga) in female subjects.

Keywords: Madhavimoola, Obesity. 


\section{INTRODUCTION}

Obesity is widely regarded as a pandemic with potentially disastrous consequences for human health. It may lead to profound social and psychological consequences for individuals. The prevalence of obesity has increased threefold with in the last 20 years and continues to rise ${ }^{3}$. When Meda (fat) is greatly increased in the body it leads to Margavrodha (channel obstruction) of Vata. The Vata Dosha gets vitiated and gives rise to various dreadful diseases ${ }^{4}$. In India, $12.1 \%$ of males and $16 \%$ of females were recorded as overweight/obese (National Family Health Survey-2007). Many studies in India have reported higher prevalence of obesity among women ${ }^{5}$. However, what is not generally recognized is the fact that obesity also has a great impact upon health outcomes for women than for men. This impact is seen in the physical, psychological and social well-being of women compared to men $^{6}$. Studies show, circulating oestrogen stores lipid deposits in gluteo-femoral region and menopause associated oestrogen deficiency results in an accumulation of adipose deposits around the abdomen and waist area. Waist circumference and Waist-Hip Ratio are both related to increased risk of all-causes mortality, throughout the range of adult BMI's ${ }^{7}$. Considering this in mind, Madhavimoola, a drug mentioned in a classic Chakradutta, is selected for the study that helps reducing the Strikati (waist) Bhaga ${ }^{8}$, when administered with Nisneha Takra (fat free buttermilk) which has Ruksha, Laghu Guna that acts as Kaphamedohara ${ }^{9}$.

Objectives: To evaluate the efficacy of Madhavimoola in the reduction of female waist circumference.

Study design: Single Arm Open Clinical Trial.

Sample size: minimum 30 females.

Methodology

Drug Distribution: After taking consent and detailed history, a special case sheet proforma was prepared and filled. On every $15^{\text {th }}$ day $\left(0^{\text {th }}, 15^{\text {th }}, 30^{\text {th }}\right.$ day $)$ the measurements as per the study criteria was taken till $45^{\text {th }}$ day. The study subjects told to take Kalka (trial drug) on daily bases, with Nisneha Takra (fat free buttermilk).

\section{Source of Data:}

a) Sample Source: 30 patients fulfilling the diagnostic and inclusion criteria, attending the OPD, camps and another referral were selected randomly. Ethical clearance number IEC No: ICEC/KC/05

b) Drug Source: Raw drug identified, collected and authenticated by the botanist, from Kunjargiri (Udupi) and Manda forest (Jammu-J\&K).

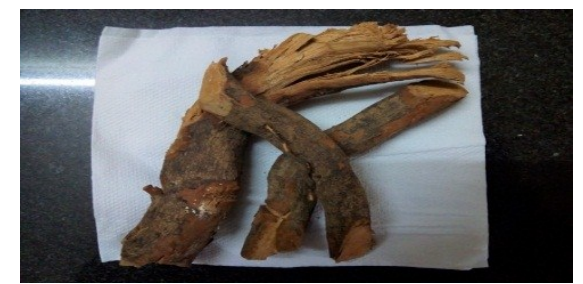

Figure 1: Roots of Hiptage benghalansis

\section{Method of Collection of Data}

i) Selection of Patients: Females fulfilling the diagnostic and inclusion criteria, irrespective of religion, occupation, socio economic status, educational status was randomly selected for the study.

ii) Diagnostic Criteria: Waist circumference $>80 \mathrm{~cm}$ (31.49 inches) -Waist-Hip Ratio $>0.85$

iii) Inclusion Criteria:

- Females fulfilling the diagnostic criteria between the age group of 16-60 years were selected.

- Increased Waist-Hip Ratio.

- Participants who gave the written consent for the clinical trial on them.

iv) Exclusion Criteria:

- Vulnerable female groups.

- Patients having major systemic disorders or other illness which may interfere with the present clinical study.

- Secondary Obesity.

v) Intervention:

- Madhavi Moola Kalka, 1 Karsha (12 gms), on empty stomach in the morning with Takra (fat free buttermilk).

vi) Observation Period:

- Total course of treatment was of 45 days 
- Assessment was done at baseline, $15^{\text {th }}, 30^{\text {th }}, 45^{\text {th }}$ day of the study.

vii. Assessment Criteria: primary and secondary outcome

- Assessment of the condition was done on the basis of detailed case proforma, adopted standard scoring methods of assessment parameters.

- Objective Criteria - Waist Circumference, Hip Circumference, Waist-Hip Ratio, BMI.

\section{Objective parameters-}

Waist circumference $(\mathrm{cm})$; Hip circumference $(\mathrm{cm})$; Waist-Hip ratio $>0.80^{10}$; Weight $(\mathrm{kg})$; Height $\left(\mathrm{mt}^{2}\right)$; BMI $^{11}$

Overweight $=25-30 \mathrm{~kg} / \mathrm{m}^{2}$, Obese grade $\mathrm{I}=30-35$ $\mathrm{kg} / \mathrm{m}^{2}$, Obese grade II $=35-40 \mathrm{~kg} / \mathrm{m}^{2}$, Obese grade III $=>40 \mathrm{~kg} / \mathrm{m}^{2}$

Subjective Criteria - Sphik Chalatva, Udara Chalatva, Stana Chalatva, Aalasya, Krichra Vyavaya, Daurbalya, Daurgandha, Swedabadha, Kshudha Atimatra, Pipasa Atiyoga, Gourava.

Table 1: Subjective parameters-

\begin{tabular}{|c|c|}
\hline 1.Sphik, Udara, Stana Chalatva: & Grade \\
\hline Absent & 0 \\
\hline Visibility of chalatva after fast movements & 1 \\
\hline Visibility of chalatva after moderate movements & 2 \\
\hline Visibility of chalatva after mild movements & 3 \\
\hline Visibility of chalatva after postural change & 4 \\
\hline \multicolumn{2}{|l|}{ 2.Aalasya: } \\
\hline No aalasya & 0 \\
\hline Satisfactory work done with late initiation & 1 \\
\hline Unsatisfactory work under mental pressure and takes time & 2 \\
\hline Not starting any work on her own responsibility and doing little work & 3 \\
\hline Does take any initiation and not want to work even after pressure & 4 \\
\hline \multicolumn{2}{|l|}{ 3.Nidra adhikya: } \\
\hline Sleep 6-7 hrs/day & 0 \\
\hline Sleep up to $8 \mathrm{hrs} /$ day + anga gaurava & 1 \\
\hline Sleep up to $8-9 \mathrm{hrs} /$ day + anga gaurava + jrimbha & 2 \\
\hline Sleep up to $10 \mathrm{hrs} /$ day + tandra & 3 \\
\hline Sleep $>10 \mathrm{hrs} /$ day + tandra + klama & 4 \\
\hline \multicolumn{2}{|l|}{ 4.Krichra vyavaya: } \\
\hline Unimpaired libido and sexual performance & 0 \\
\hline Decrease in libido but, can perform sexual act & 1 \\
\hline Decrease in libido but, can perform sexual act with difficulty & 2 \\
\hline Loss of libido and cannot perform sexual act & 3 \\
\hline \multicolumn{2}{|l|}{ 5.Daurbalya/ Krichra Vyayama: } \\
\hline Can do routine exercise & 0 \\
\hline Can do moderate exercise without difficulty & 1 \\
\hline Can do only mild exercise & 2 \\
\hline Can do mild exercise with difficulty & 3 \\
\hline Cannot do even mild exercise & 4 \\
\hline \multicolumn{2}{|l|}{ 6.Daurgandha: } \\
\hline Absence of foul smell & 0 \\
\hline Occasional bad smell from body, removed after bathing & 1 \\
\hline
\end{tabular}




\begin{tabular}{|l|l|}
\hline Persistent bad smell limited to close areas, difficult to supress with deodorant & 2 \\
\hline Persistent bad smell limited to close areas, difficult to supress with deodorant & 3 \\
\hline Persistent bad smell felt from long distance even intolerable to the patient herself & 4 \\
\hline 7.Swedabadha: & 0 \\
\hline Sweating after heavy work/ fast movement/ in hot season & 1 \\
\hline Profuse sweating after moderate work and movement & 2 \\
\hline Sweating after little work and movement & 3 \\
\hline Profuse sweating after little work and movement & 4 \\
\hline Sweating even at rest or in cold climate & \\
\hline 8.Pipasa atiyoga: & 0 \\
\hline Able to withstand thirst for more than 5 hrs. & 1 \\
\hline Able to withstand thirst for not $>4$ hrs. & 2 \\
\hline Able to withstand thirst for not $>3$ hrs. & 3 \\
\hline Able to withstand thirst for not $>2$ hrs. & 4 \\
\hline Able to withstand thirst for not $>1$ hr. & \\
\hline 9.Kshudha atiyoga: & 0 \\
\hline Tolerate hunger above 3 hrs. & 1 \\
\hline Tolerate hunger up to 3 hrs. with irritability & 2 \\
\hline Tolerate hunger up to 2 hrs. & 3 \\
\hline Tolerate hunger up to 2 hrs. with irritability & 4 \\
\hline Cannot tolerate hunger for 1 hr. & \\
\hline 10.Gaurava: & 0 \\
\hline No heaviness in the body & 1 \\
\hline Heaviness in the body does not hampers routine work & 2 \\
\hline Heaviness in the body hampers routine work & 3 \\
\hline Heaviness in the body restricts routine work & 4 \\
\hline Heaviness in the body destroys the routine work & \\
\hline
\end{tabular}

Statistical analysis: Statistical Test of Significance paired ' $t$ ' test was implemented to test the hypothesis of the study, where the objective criteria was assessed statistically, and conclusion drawn on the basis of before and after completion of treatment. For the subjective criteria, Wilcoxon Signed Rank Test was implemented.

Observations \& Results: Among the 30 patients, maximum patients belonged to age group 31-45 years. Most of them belonged to Hindu religion (25 patients), married (26 patients) with the positive family history (21 patients) and sedentary lifestyle (26 patients). Maximum were recorded with Adhyashana,
Mandagni, Madhyama Koshtha, Kapha Vata Prakruti, Madhyama - Satwa, Satmya, Sara, Samhanana, Pramana, Aahara Shakti and Avara Vyayama Shakti. Results obtained after the clinical trial were analysed statistically and interpreted on the basis of assessment criteria before and after treatment. The final result showed that on $45^{\text {th }}$ day of treatment, 12 patients (40\%) showed minimal relief, 9 patients (30\%) showed mild relief, 5 showed $(16.66 \%)$ moderate relief, 1 patient $(3.33 \%)$ showed marked relief and 3 patients showed $(0 \%)$ no improvement. The clinical results for objective criteria were found to be statistically significant at $\mathrm{p}<0.001$, except for $\mathrm{BMI}=0.161$.

Table 2: Effect of treatment on $45^{\text {th }}$ day, on 30 patients in objective criteria: 


\begin{tabular}{|l|l|l|l|l|l|l|l|l|}
\hline Criteria & BT mean & AT mean & Difference in mean & $\%$ & SD & SE & t- value & P value $(95 \%$ CI) \\
\hline WC & 41.23 & 38.30 & 2.93 & 7.10 & 3.534 & 0.645 & 7.150 & $<0.001$ \\
\hline HC & 45.25 & 44.31 & 0.94 & 2.07 & 4.617 & 0.843 & 4.296 & $<0.001$ \\
\hline WHR & 0.90 & 0.86 & 0.04 & 4.44 & 0.0799 & 0.0146 & 4.993 & $<0.001$ \\
\hline BMI & 32.09 & 31.74 & 0.35 & 1.09 & 4.526 & 0.826 & 1.439 & $=0.161$ \\
\hline Wt. & 78.21 & 76.88 & 1.33 & 1.70 & 12.319 & 2.249 & 4.431 & $<0.001$ \\
\hline
\end{tabular}

Table 3: Effect of treatment on $15^{\text {th }}, 30^{\text {th }}, 45^{\text {th }}$ day on 30 patients in Udara chalatva:

\begin{tabular}{|l|l|l|l|l|l|l|l|l|}
\hline Criteria & BT mean & AT mean & Difference in mean & $\%$ & SD & SE & z- value & P value \\
\hline $15^{\text {th }}$ day & 44 & 44 & 0 & 0 & 1.0080 & 0.1840 & 0.000 & $=1.000$ \\
\hline $30^{\text {th }}$ day & 44 & 37 & 7 & 15.90 & 0.9353 & 0.1708 & -2.646 & $=0.016$ \\
\hline $45^{\text {th }}$ day & 44 & 34 & 10 & 22.72 & 0.8604 & 0.1571 & -3.162 & $=0.002$ \\
\hline
\end{tabular}

Statistical analysis of single group study, showed that the mean of Udara Chalatva was 44 before treatment and after $15^{\text {th }}$ day it was same, after analysing statistically, the change that occurred with the treatment is not great enough to exclude the possibility that it is due to chance $(\mathrm{P}=1.000)$. After $30^{\text {th }}$ day it was reduced to 37 after treatment. When these values were analysed statistically, the change that occurred with the treatment is greater than would be expected by chance; there is a statistically significant difference $(\mathrm{P}$ $=0.016)$. On $45^{\text {th }}$ day reduction was observed up to 34 and after analysing statistically, the change that occurred with the treatment is greater than would be expected by chance, there is a statistically significant difference $(\mathrm{P}=0.002)$.

Table 4: Effect of treatment on $15^{\text {th }}, 30^{\text {th }}, 45^{\text {th }}$ day on 30 patients in Stana Chalatva:

\begin{tabular}{|l|l|l|l|l|l|l|l|l|}
\hline Criteria & BT mean & AT mean & Difference in mean & \% & SD & SE & z- value & P value \\
\hline $\mathbf{1 5}^{\text {th }}$ day & 42 & 42 & 0 & 0 & 1.0700 & 0.1953 & 0.000 & $=1.000$ \\
\hline $\mathbf{3 0}^{\text {th }}$ day & 42 & 38 & 4 & 9.52 & 1.0148 & 0.1853 & -2.000 & $=0.125$ \\
\hline $\mathbf{4 5}^{\text {th }}$ day & 42 & 35 & 7 & 16.66 & 0.9499 & 0.1734 & -2.646 & $=\mathbf{0 . 0 1 6}$ \\
\hline
\end{tabular}

Statistical analysis of single group study, showed that the mean of Stana Chalatva was 42 before treatment and after $15^{\text {th }}$ day it was same, after analysing statistically, the change that occurred with the treatment is not great enough to exclude the possibility that it is due to chance $(\mathrm{P}=1.000)$. After $30^{\text {th }}$ day it was reduced to 38 after treatment. When these values were analysed statistically, the change that occurred with the treatment is not great enough to exclude the possibility that it is due to chance $(\mathrm{P}=0.125)$. On $45^{\text {th }}$ day reduction was observed up to 35 and after analysing statistically, the change that occurred with the treatment is greater than would be expected by chance, there is a statistically significant difference $(\mathrm{P}=$ 0.016).

Table 5: Effect of treatment on $15^{\text {th }}, 30^{\text {th }}, 45^{\text {th }}$ day on 30 patients in Daurbalya:

\begin{tabular}{|l|l|l|l|l|l|l|l|l|}
\hline Criteria & BT mean & AT mean & Difference in mean & $\%$ & SD & SE & z- value & P value \\
\hline $15^{\text {th }}$ day & 45 & 45 & 0 & 0 & 1.2798 & 0.2337 & 0.000 & $=1.000$ \\
\hline $30^{\text {th }}$ day & 45 & 42 & 3 & 6.66 & 1.2205 & 0.2228 & -1.732 & $=0.250$ \\
\hline $45^{\text {th }}$ day & 45 & 39 & 6 & 13.33 & 1.1492 & 0.2098 & -2.449 & $=0.031$ \\
\hline
\end{tabular}

Statistical analysis of single group study, showed that the mean of Daurbalya was 45 before treatment and after $15^{\text {th }}$ day it was same, after analysing statistically, the change that occurred with the treatment is not 
great enough to exclude the possibility that it is due to chance $(\mathrm{P}=1.000)$. After $30^{\text {th }}$ day it was reduced to 42 after treatment. When these values were analysed statistically, the change that occurred with the treatment is not great enough to exclude the possibility that it is due to chance $(\mathrm{P}=0.250)$. On $45^{\text {th }}$ day reduction was observed up to 39 and after analysing statistically, the change that occurred with the treatment is greater than would be expected by chance, there is a statistically significant difference $(\mathrm{P}=0.031)$.

Table 6: Overall improvement observed after treatment in 30 patients on $45^{\text {th }}$ day:

\begin{tabular}{|l|l|l|}
\hline Improvement & No. of patients & Percentage \\
\hline Complete improvement $(100 \%)$ & 0 & 0 \\
\hline Marked improvement $(75-99 \%)$ & 1 & 3.33 \\
\hline Moderate improvement $(50-74 \%)$ & 5 & 16.66 \\
\hline Mild improvement $(25-49 \%)$ & 9 & 30 \\
\hline Minimal improvement $(1-24 \%)$ & 12 & 40 \\
\hline No improvement $(0 \%)$ & 3 & 10 \\
\hline
\end{tabular}

The patients who reduced waist circumference up to 1-2 inches, were considered to be minimally improved, on reducing 3-4 inches mildly improvement was recorded. Moderate improvement was documented if patient reduced 5-6 inches, only 1 patient showed marked improvement with the reduction of 6.4 inches and no improvement was recorded when no marked change (less than 1 inch) was observed on $45^{\text {th }}$ day (last day).

Untoward Symptoms: 1 patient out of 30 patients complained of pustules over axilla, thigh and abdomen, but continued the treatment as she was responding to the trial drug. Pustules subsided after the 3 days of the treatment completion.

\section{DISCUSSION}

On Trial Drug: The trial drug (Madhavilata) have Laghu and Sheeta Guna, Katu-Tikta-Kashaya and Madhura Rasa, Sheeta Virya, Madhura Vipaka and Tridoshaghana properties. [qualities of the above Guna $\rightarrow$ Rooksha, Ushna, Laghu, Teekshna, Vishada, Kaphaghana, Langhana Karaka, Srotas Shodhaka, Karshaya Karaka, Agni Deepaka, Utsaha Karaka all these acts opposite to the properties of Kapha and Meda, that leads to Medoroga. $]^{12}$ Phytochemicals in root bark - Alkaloids (a bioactive component having promising effect in tackling obesity), Tannins (tannic acid is a major component of tannins, documented to stimulate the glucose transport and inhibits adiposity), Reducing sugar ${ }^{13}$.
On Kala: The medicine has to be administered in the period of Ananna/Abhakta Kala (on empty stomach, early in the morning). Since, this is the time of administration for drug in Kaphaudreka, Balwan Roga and Rogi (Anaanna Kala - empty stomach), Apana Vayu Vaigungya, on empty stomach before food ${ }^{14}$.

On Anupana: Here, Takra is taken as Anupana. According to Acharya Sushruta ${ }^{15}$, Takra prepared by adding the water in curd (1/2: 1), after churning it properly extract the whole butter, the left fluid is Nisneha Takra. Having the properties Madhura-AmlaKashaya Rasa, Laghu-Rooksha Guna, Ushna Virya, Madhura Vipaka and Kapha-Vatahara. Moreover, it is well known for its digestive property and administration in Kapha-Medo Roga.

\section{Effect of Therapy on objective criteria:}

The result of the study/clinical trial suggests that there is a significant change in all the objective criteria except BMI, which was also proved statistically.

Waist circumference- Test showed highly significant change with $P$ value $<0.001$., Hip circumference- Test showed highly significant change with $\mathrm{P}$ value $<0.001$., Waist-Hip Ratio- Test showed highly significant change with $\mathrm{P}$ value $<0.001$., BMI- Test showed non-significant change with $\mathrm{P}$ value $=0.161$., WeightTest showed highly significant change with $\mathrm{P}$ value $<0.001$.

Effect of therapy on Lakshana (Subjective Criteria): After the therapy, mild improvement on Lakshana was recorded like in Udara-Stana Chalatva and 
Daurbalya. Statistical analysis by using Wilcoxon Signed Rank Test, Stat-32, Sigma Stat 4.0 version was done on the data collected showed, HS (highly significant) $=0.002$ effect seen in Udara chalatva on $45^{\text {th }}$ day. In Stana Chalatva, Daurbalya, Swedabadha and Atikshudha significant effects seen statistically, on $45^{\text {th }}$ day.

\section{CONCLUSION}

Medo roga is Santarpanotha Shleshmaja Vikara considered as an independent disease, placed under the umbrella of lifestyle disorders, but it is the cause for various diseases too. It is characterised by excessive fat accumulation in different body parts, especially Udara-Stana-Sphik, causing its Chalatva. In this study, the main cause for increased female waist size was observed to be due to Beejaswabhavaja, followed by Avyayama. Maximum number of patients in the study belonged to service class followed by housewives, irregular, untimely eating and sleeping lead to this disease. Mixed diet, sedentary lifestyle, family history for the Medoroga and increased waist circumference was documented during the trial. As said "Prevention is better than cure" the phrase fits for this Roga well, hence, Medoroga is a Krichra Sadhya Vyadhi, (cured with difficulty) by following healthy regimen the disease can be prevented.

Limitation of the study: The patients were allowed to continue their regular routine (except additional sugar consumption).

\section{REFERENCES}

1. Agnivesha, Charka Samhita with Vaidyamanorama Hindi Commentary by Acharya Vidyadhar Shukla and Prof. Ravi Dutt Tripathi, Redacted by Drdhabala, Published by Chaukhamba Sanskrit Pratishthan Delhi; 2006. Sutra Sthana 21/5-9, 28/3, Pp-301,426.

2. Vruddha Vagbhata, Ashtanga Samgraha with Sasilekha Sanskrit Commentary by Indu, Prolouge in Sanskrit \& English by Prof. Jyotir Mitra, Edited by Dr. Shivaprasad Sharma, Published by Chaukhamba Sanskrit Series Office Varanasi; Sutra Sthana 23/6, Pp-177.

3. Brain R. Walker, C. Summerton, M. Byers, P. Hanlon, Davidson's Principle and Practices of Medicine, Edition $20^{\text {th }} 2006$; Reprinted 2008, Chapter-5, Page-111.

4. Bhavamishra, Bhavaprakash by Prof. K.R. Srikantha Murthy, Vol. II, Edition $4^{\text {th }}, 2009$, Published by Chau- khamba Krishna Das Academy, Varanasi; Chapter 39/8-9, Page 502-512.

5. Internet source: http://en.m.wikipedia.org/wiki/Obesity-in-India http://en.m.wikipedia.org/wiki/Body-Mass-Index_Waist Circumference and Waist-Hip-Ratio (WHO) Report of a WHO Expert Consultation Geneva, 8-11 Dec.2008 whqlibdoc.who.int $>9789241501491$

6. https://journals./www.com>FullText $>$ Introduction Introduction: Obesity and Lifestyle issues in women: clinical obstetrics and gynaecology. Women and Obesity: its more than an issue of size.

7. Internet source: Waist Circumference and Waist-HipRatio (WHO) Report of a WHO Expert Consultation Geneva, 8-11 Dec. 2008 whqlibdoc. who.int $>9789241501491$

8. Chaktadutta of Acharya Chakradutta by Prof. Priya Vrat Sharma, Edition 2007, Published by Chaukhamba Orientalia, New Delhi; Chapter-63/67, Page-544.

9. Sushruta Samhita of Acharya Sushruta by Prof. K.R. Srikantha Murthy, Vol.I Sutra Sthana 45/84-85, Reprint Edition: 2016, Published by Chaukhamba Orientalia Varanasi; Page-342.

10. www.meandmywaist.com

11. The International classification of adult underweight, overweight and obesity according to BMI. (source: WHO, 1995, WHO, 2000 \& WHO 2004)

12. Prof. Priya Vrat Sharma, Dravyaguna Vigyana, Vol.1, Khanda 2, Edition 2007, Published by Chaukhamba Orientalia, New Delhi; Page-137-230.

13. Phytochemical analysis of the methanol extract of root bark of Hiptage benghalensis (L.) Kurz by Lalnundanga, Lalchaimawii Ngente, March 2012, MIPOGRASS.

14. Vagbhata, Ashtanga Hridayam, Commentator Dr. Gyanendra Pandey, Publisher Chawkhamba Sanskrit Series Office, Varanasi; First edition 2008, Sutra Sthana 13/38, Pp-344.

15. Divodasa Dhanvantari, Sushruta Samhita, edited with Ayurveda-Tattva-Sandipika by Kaviraja Ambikadutta Shastri, Published by Chaukhamba Sanskrit Sansthan, Varanasi; Reprint 2015, Vol I, Sutra Sthana 45/85, Pp227.

\section{Source of Support: Nil \\ Conflict of Interest: None Declared}

How to cite this URL: Aabha Sharma: To Evaluate The Efficacy Of Madhavimoola (Hiptage Benghalansis Root) As Stri Katibhaga Ksheenaka Yoga - A Pilot Study. International Ayurvedic Medical Journal \{online\} 2020 \{cited October, 2020\} Available from: http://www.iamj.in/posts/images/upload/4593 4599.pdf 